\title{
Structural ambidexterity in NPD processes: A firm-level assessment of the impact of differentiated structures on innovation performance
}

\author{
Matthias de Visser ${ }^{\mathrm{a}, *}$, Petra de Weerd-Nederhof ${ }^{\mathrm{a}, 1}$, Dries Faems ${ }^{\mathrm{a}, 2}$, Michael Song ${ }^{\mathrm{b}, 3}$, Bart van Looy ${ }^{\mathrm{c}, 4}$, \\ Klaasjan Visscher ${ }^{\mathrm{a}, 5}$ \\ ${ }^{a}$ University of Twente, Capitool 15, 7521 PL Enschede, The Netherlands \\ ${ }^{\mathrm{b}}$ University of Missouri-Kansas City, 5100 Rockhill Road, Kansas City, MO 64110-2499, USA \\ ${ }^{\text {c } K a t h o l i e k e ~ U n i v e r s i t e i t ~ L e u v e n, ~ N a a m s e s t r a a t ~ 69, ~} 30000$ Leuven, Belgium
}

\section{A R T I C L E I N F O}

Keywords:

New product development process

Cross-functional structure

Structural ambidexterity

Derivative innovation performance

Breakthrough innovation performance

\begin{abstract}
A B S T R A C T
Based on a survey study of 155 U.S. firms, we conducted a firm-level assessment of the impact of different kinds of structures (i.e., functional versus cross-functional) in different kinds of new product development (NPD) processes (i.e., incremental versus radical) on different kinds of firm innovation performance (i.e., derivative versus breakthrough). We observe that most firms opt for similar structures for their incremental and radical NPD processes. At the same time, though, we find strong evidence that (1) firms that apply a cross-functional structure for the radical NPD process perform significantly better in terms of breakthrough innovation performance than firms that apply a functional structure for the radical NPD process and (2) firms that apply a functional structure for the incremental NPD process perform significantly better in terms of derivative innovation performance than firms that apply a cross-functional structure for the incremental NPD process. These latter findings point to the relevance of adopting structural ambidexterity, where firms make an explicit distinction between incremental and radical NPD processes and organize them in a different way.
\end{abstract}

(c) 2009 Elsevier Ltd. All rights reserved.

\section{Introduction}

New product development (NPD) is seen as crucial for the long-term survival and growth of the firm (Baumol, 2002; Schumpeter, 1939). During the past decades, scholars have therefore increasingly studied the NPD process within firms ${ }^{6}$ (for an overview of this research, see Damanpour, 1991; Brown and Eisenhardt, 1995; Cooper, 1999; Ernst, 2002; Barczak et al., 2009). In these studies, the structural design of the NPD process has been recognized as one of the critical factors in arriving at successful innovation (Cooper, 2003). In particular, the implementation of structural mechanisms such as cross-functional structures (Griffin, 1997; Song et al., 1997), stage-gate processes

\footnotetext{
* Corresponding author. Tel./fax: +31534892768.

E-mail addresses: m.devisser@utwente.nl (M. de Visser), p.c.deweerd@utwente. nl (P. de Weerd-Nederhof), d.l.m.faems@utwente.nl (D. Faems), songmi@umkc.edu (M. Song), Bart.VanLooy@econ.kuleuven.be (B. van Looy), k.visscher@utwente.nl (K. Visscher).

1 Tel.: +31534893499.

2 Tel.: + 31534894398 .

3 Tel.: +1816235 5841 .

4 Tel.: + 3216326901 .

5 Tel.: +31534893489.

${ }^{6}$ Recently, scholars (e.g., Faems et al., 2005; Rothaermel and Deeds, 2004) have also started examining the NPD process between firms. However, in this article we only focus on internal NPD.
}

(Canez et al., 2007; Cooper, 1996), and formalized NPD procedures (Booz et al., 1982; Schmidt et al., 2009) have been found to positively influence the innovation performance of firms.

At the same time, it is increasingly recognized that the NPD process is a multidimensional phenomenon, encompassing development processes that focus on the improvement of existing products (incremental NPD processes) as well as processes that focus on the generation of new products (radical NPD processes). Moreover, several scholars (Olsen et al., 1995, 2001; Song and Xie, 2000) have provided evidence that, within a particular NPD project, the product innovativeness moderates the relationship between the effectiveness of the structure (i.e., formal versus cross-functional) and the performance of the NPD project. However, these studies have solely focused on the project level (Sánchez and Pérez, 2003). As a result, we do not know whether firms tend to apply different kinds of structures for different kinds of NPD processes and how the application of particular structures in NPD processes influences firm-level innovation performance. In this study, therefore, we conduct a firm-level assessment of the impact of different kinds of structures (i.e., functional versus cross-functional) in different kinds of NPD processes (i.e., incremental versus radical) on different kinds of firm innovation performance (i.e., derivative versus breakthrough).

Based on a survey study of 155 US firms, we observe that most firms apply similar structures for their incremental and radical NPD processes. At the same time, though, we find strong evidence 
that (1) firms that apply a cross-functional structure for the radical NPD process perform significantly better in terms of breakthrough innovation performance than firms that apply a functional structure for the radical NPD process and (2) firms that apply a functional structure for the incremental NPD process perform significantly better in terms of derivative innovation performance than firms that apply a cross-functional structure for the incremental NPD process. In other words, our findings point to the relevance of adopting structural ambidexterity (Gibson and Birkenshaw, 2004; O'Reilly and Tushman, 2004), where firms make an explicit distinction between incremental and radical NPD processes and organize them in a different way.

The remainder of this article consists of four sections. In Section 2 we situate our study in the existing NPD literature. In Section 3, we discuss our methodology. Subsequently, in Section 4, we present our results. Finally, in Section 5, we point to the theoretical and managerial implications of our findings, discuss the limitations of our study, and suggest interesting avenues for future research.

\section{Theoretical background and hypotheses}

\subsection{A project-level assessment of the structure-performance relationship}

Numerous scholars (e.g., Cormican and O'Sullivan, 2004; Griffin, 1997; Griffin and Hauser, 1992; Gupta et al., 1986; Pinto and Pinto, 1990) have examined the structure of the NPD process and how it influences NPD performance. These studies emphasize that firms can choose between different kinds of structures for the NPD process. On the one hand, firms can choose a functional approach, where various specialized departments (research and development [R\&D], manufacturing, and marketing) work independently (Song et al., 1998). The antithesis of a functional approach to structure NPD is the cross-functional structure, where specialists of different departments are brought together within a single team structure for a particular NPD project (Griffin, 1997).

In the NPD literature (e.g., Eisenhardt and Tabrizi, 1995; Ernst, 2002; Garcia et al., 2008; Griffin, 1997; Lee and Chen, 2007), the advantages of cross-functional structures for NPD projects have been emphasized. Cross-functional project teams foster interdepartmental communication and cooperation which in turn facilitate coordination (Ernst, 2002). In addition, the presence of an NPD team, which is composed of members with various functional specializations, facilitates access to a diverse pool of information, which increases the probability of successful innovation (Balbontin et al., 1999). Such cross-functional structure also allows engaging in overlapping development stages, which in turn speeds up the development process (Brown and Eisenhardt, 1995).

However, some scholars (Moenaert et al., 1995; Olsen et al., 1995; Song et al., 1998; Song and Xie, 2000), adopting a contingency perspective, have argued that the relationship between cross-functional structures and innovation performance is more complex. In particular, they provide evidence that certain contingencies may moderate the relationship between the effectiveness of cross-functional structures and the outcomes of NPD projects. The degree of project innovativeness has been recognized as an important contingency in this respect (Olsen et al., 1995; Song and Xie, 2000). The degree of innovativeness can vary between incremental and radical NPD processes (Dewar and Dutton, 1986; Tushman and Anderson, 1986). The objective of incremental NPD processes is to improve existing products through conducting exploitative activities such as optimization, standardization, and refinement. Within radical NPD processes, the objective is to generate really new products through conducting explorative activities such as fundamental research, experimenting, and prototyping (Tushman and Smith, 2002).

Relying on resource dependence theory, scholars (e.g., Gupta et al., 1986; Olsen et al., 1995, 2001; Ruekert and Walker, 1987) have argued that product innovativeness might influence the need for cross-functional structures in NPD projects. In particular, it is emphasized that radical innovation projects are associated with high levels of external and internal uncertainty, triggering substantial task interdependence between the involved project members. To address such increased interdependence levels, more participative coordination structures such as crossfunctional teams become necessary. In contrast, incremental innovation projects typically are characterized by relatively low levels of uncertainty. In such circumstances, task interdependence levels are likely to be relatively low, reducing the need for participative coordination structures.

Adopting insights from information-processing theory, other scholars have come to similar conclusions. They argue that, within radical innovation projects, the need to bring together organizational members with diverse backgrounds is relatively high. Schön (1963), for instance, argues that novel solutions and insights ask for problem-defining and problem-solving interaction sequences, whereby multiple opinions and viewpoints become integrated into a new synthesis or artifact. Similarly, Pelz and Andrews (1966) conclude that differences in approaches between individuals may provide the intellectual jostling or "dither", which is needed for really creative work. In addition, scholars have pointed to cross-functional structures as an effective coordination mechanism to bring together members of diverse backgrounds. Allen (2001) and Hargadon (2003), for instance, emphasize that, when domain specialists are integrated in a cross-functional team, these specialists can contribute to connecting previously unrelated knowledge sets, thereby stimulating breakthrough innovation.

At the same time, though, indications are present that, because of such increased diversity, cross-functional structures might be less beneficial for NPD projects of a more incremental nature. Bringing together members of diverse backgrounds also leads to conflicting expectations and an excess of opinions from different individuals (Song et al., 1998). This might lead to disruption of existing work routines and difficult decision making, which in turn hampers the ability for continuous optimization and refinement of existing products and technologies (Song and Xie, 2000).

On the level of individual NPD projects, empirical evidence supports the moderating impact of product innovativeness on the relationship between the effectiveness of cross-functional structures and project performance. Examining 45 NPD projects, Olsen et al. (1995) provide evidence that product innovativeness moderates the relationship between the effectiveness of coordination structures and project success. In particular, they observe that the better the fit between the newness of the product concept and the participatory nature of the structure used, the better the outcomes of the development process in terms of (1) objective measures of product and team performance, (2) the attitudes of team members toward the process, and (3) the efficiency and timeliness of the NPD process. More recently, other scholars have provided more fine-grained assessments of the moderating impact of product innovativeness on the relationship between structures and the performance of single NPD projects. Based on data from 788 Japanese and 612 US NPD projects, Song and Xie (2000) found that product innovativeness significantly moderates the structure-performance relationship in Japanese firms but not in US firms. Relying on fine-grained data from 34 NPD processes, Olsen et al. (2001) observe that (1) late-stage cooperation between marketing and operations and R\&D and operations is a key determinant of project performance for innovative products 
but not for noninnovative products and (2) early-stage cooperation between marketing and operations is associated with superior performance for low-innovation projects but is also associated with poor performance for highly innovative projects.

\subsection{Toward a firm-level assessment of the structure-performance relationship}

Although previous studies have provided valuable insights into how product innovativeness moderates the structure-performance relationship at the individual project level, a firm-level assessment of the impact of different structures on innovation performance is lacking. We therefore do not know whether single firms tend to use different kinds of structures for different kinds of NPD processes or rather whether they prefer to apply a homogenous structural regime across different kinds of NPD processes.

Firm-level studies on innovation (e.g., Gibson and Birkinshaw, 2004; Raisch and Birkinshaw, 2008; O'Reilly and Tushman, 2004; Tushman and Anderson, 1986; Tushman and O'Reilly, 1996; Van Looy et al., 2005; Jansen et al., 2006) suggest that, if a company wants to excel in both improving existing products (i.e., derivative innovation performance) and generating new products (i.e., breakthrough innovation performance), the company should engage in different kinds of innovation activities. In particular, exploitative activities such as optimization, standardization, and refinement are linked to derivative innovation performance, whereas explorative activities such as fundamental research, experimentation, and search are connected to breakthrough innovation performance (Benner and Tushman, 2003; Li et al., 2008). Relying on insights from organizational learning theory (e.g., March, 1991; Levinthal and March, 1993), it is also stressed that simultaneously conducting exploitative and explorative activities is not a straightforward task as these activities require radically different mindsets and organizational routines (Gupta et al., 2006). In addition, as exploitative and explorative activities compete for scarce resources within firms, more focus on exploitation (exploration) is likely to imply less attention to exploration (exploitation).

In the firm-level innovation literature, numerous scholars (e.g., Benner and Tushman, 2003; Jansen et al., 2006; O'Reilly and Tushman, 2004) point to structural ambidexterity as an effective organizational strategy to address the tension between exploitation and exploration. Structural ambidexterity refers to the separation of exploitative and explorative activities into distinct organizational units (Gibson and Birkenshaw, 2004; Raisch et al., 2009). In this way, each type of activity gets its own organizational space, where it can be managed in its own particular way (Raisch and Birkinshaw, 2008). For instance, O'Reilly and Tushman (2004) emphasize that, whereas a more mechanistic organizational structure can be applied for the exploitation-oriented business units, more organic structures can be implemented in the exploration-oriented business units. In a similar vein, Jansen et al. (2006) provide evidence that exploitative business units perform better with high levels of formalization whereas explorative business units might benefit from low levels of centralization.

In sum, existing firm-level studies on innovation suggest the relevance of making an explicit distinction between incremental and radical NPD processes and organizing them in different ways (i.e., structural ambidexterity). Based on these arguments, we hypothesize that:

Hypothesis 1. Firms apply different structures (i.e., functional versus cross-functional) for different kinds of NPD processes (i.e., incremental versus radical).
In addition, because of the previous focus on single projects in structure-performance studies, we lack empirical data on how the application of specific structures in specific kinds of NPD processes influences the ability of firms to generate sales from product improvements (i.e., derivative innovation performance) and from radically new products (i.e., breakthrough innovation performance). We therefore assess the following hypotheses:

Hypothesis 2. Firms that apply a functional structure for their incremental NPD process display significantly higher levels of derivative innovation performance than firms that apply a crossfunctional structure for their incremental NPD process.

Hypothesis 3. Firms that apply a cross-functional structure for their radical NPD process display significantly higher levels of breakthrough innovation performance than firms that apply a functional structure for their radical NPD process.

\section{Methodology}

\subsection{Data and sample}

Our sample population consisted of 500 randomly selected nonservice US firms listed in the World Business Directory. We sent a presurvey letter to all 500 firms requesting preapproval of participation. A total of 186 firms agreed to participate and provided a contact person, while 36 companies declined to participate, 42 letters were returned due to invalid contact person or address, and 236 companies did not respond.

In administering the final survey, we followed Dillman's (1978) total design method for survey research. The first mailing packet included a personalized letter, the survey, a priority postage-paid envelope with an individually typed return address label, and a list of research reports available to participants. The package was sent by priority mail to 422 firms (186 firms agreeing to participate and 236 nonresponding firms from the presurvey). We asked the contact person (president, division manager, strategic business manager, new business program manager, or $\mathrm{R} \& \mathrm{D}$ director) to distribute the questionnaire to a manager who has been involved in developing new products in their organization or who has knowledge of overall new product programs in their organization.

To increase the response rate, we sent four follow-up mailings to the companies. One week after the mailing, we sent a follow-up letter. Two weeks after the first follow-up, we sent a second package with the same contents as the first package to all nonresponding companies. After two additional follow-up letters, we received usable questionnaires from 155 firms, representing a response rate of $38 \%(155 / 422)$.

The industries represented in the final sample are: Chemicals and Related Products; Electronic and Electrical Equipment; Pharmaceutical, Drugs, and Medicines; Industrial Machinery and Equipment; Telecommunications Equipment; Semiconductors and Computer-Related Products; and Instruments and Related Products. The annual sales of respondent firms ranged from $\$ 500,000$ to $\$ 461$ million and the total number of employees in the business unit ranged from 11 people to 1017 people.

\subsection{Measures}

\subsubsection{Dependent variables: indicators of innovation performance}

Following Faems et al. (2005) we used the composition of turnover in 2005 in order to make a distinction between derivative and breakthrough innovation performance. The proportion of turnover in 2005 attributed to breakthrough new products that were introduced during the last 3 years is regarded as an 
indication of breakthrough innovation performance. Likewise, the percentage of turnover in 2005 attributed to improved products that were introduced during the last 3 years is seen as an indicator of derivative innovation performance. In line with the study by Faems et al. (2005), in order to obtain a normal distribution our analyses include the logarithm of $1+$ the proportion of turnover attributed to (1) breakthrough new products and (2) improved products.

\subsubsection{Independent variable: structure}

The purpose of this study is to examine to what extent the structure of the incremental and radical NPD processes influences the innovation performance of firms. Based on previous research on the structuring of NPD processes (i.e., Griffin, 1997; Griffin and Page, 1996) we made a distinction between two different ways to structure the NPD process: (1) functional structure and (2) crossfunctional structure. In addition, we made an explicit distinction between the incremental and radical NPD processes. In particular, we first asked respondents to indicate which kind of structure they applied for organizing the incremental development processes. Next, we asked respondents to indicate the applied structure for organizing the radical development processes. Based on these questions, we constructed two dummy variables, representing the applied structure within (1) the incremental NPD processes and (2) the radical NPD processes. If firms applied a functional structure for their incremental/radical NPD processes, they received a value of 0 . If firms applied a cross-functional structure for their incremental/radical NPD processes, they received a value of 1 .

\subsubsection{Control variables}

Previous studies (e.g., Barczak et al., 2009; Cooper, 2001; Cooper and Edgett, 2008; Griffin, 1997) have provided evidence that firms can differ in terms of the extent to which their NPD strategy is professionalized. Moreover, these studies indicate that the professionalization of the NPD strategy might impact a firm's innovation performance. For instance, Cooper et al. (2004) identified a clear and well-communicated NPD strategy as one of the most important performance drivers for new product success. In this study, we therefore measured the professionalization of a firm's NPD strategy. In particular, we asked respondents to indicate on a seven-point Likert-type scale to what extent they applied the following five strategy-related NPD best practices as identified by Cooper and Kleinschmidt (1995), and Cooper et al. (2004): (1) the role of NPD in achieving business goals is clearly articulated, (2) there is a formally stated NPD strategy, (3) we have clearly defined goals for all of our individual new products, (4) systematic portfolio management is in place, and (5) the project portfolios are aligned with the business strategy. Reliability analysis indicated that these five items represented one single construct (Cronbach's $\alpha=.72$ ). We therefore built the construct professionalization of NPD strategy by calculating the mean of the scores on these five items.

Another factor that may influence a firm's innovation performance is organizational climate (Ernst, 2002). Several scholars (e.g., Cooper et al., 2004; Ekvall, 1996; Van Der Vegt et al., 2005) have argued that an organizational climate that is characterized by intrapreneurship, risk-taking behaviour, and mutual trust (Cooper, 2001) will stimulate innovation. We therefore introduced innovative climate as a control variable in our analyses. Innovative climate was measured on a six-item scale that we adopted from Parry et al. (2009). This scale measures the degree to which employees are emotionally involved in their goals, trust each other, have conflicts, have freedom to define their work, and have time and support to develop new ideas. Reliability analysis indicated that these six items represented one single construct (Cronbach's $\alpha=.84$ ).
Table 1

Sector frequencies and percentages.

\begin{tabular}{lcc}
\hline Sector & Frequency & Percent \\
\hline Automotive & 20 & 12.9 \\
Chemical & 13 & 8.4 \\
Electronics & 7 & 4.5 \\
Instruments & 12 & 7.7 \\
Leather & 16 & 10.3 \\
Metal & 48 & 31.0 \\
Stone & 18 & 11.6 \\
Textile & 17 & 11.0 \\
Other & 4 & 2.6 \\
\hline
\end{tabular}

Table 2

Incremental and radical NPD process types (frequencies and percentages).

\begin{tabular}{lcc}
\hline & Frequency & Percent \\
\hline Incremental NPD process & & \\
$\quad$ Functional structure & 20 & 12.9 \\
Cross-functional structure & 135 & 87.1 \\
Total & 155 & 100 \\
Radical NPD process & & \\
Functional structure & 40 & 25.8 \\
Cross-functional structure & 115 & 74.2 \\
Total & 155 & 100 \\
\hline
\end{tabular}

In order to control for industry effects, we made a distinction between sectors based on the Standard Industrial Classification. Table 1 displays the frequencies and percentages of the sectors in our data collection.

In the NPD literature, considerable attention is devoted to the relationship between firm size and innovation performance (e.g. Schumpeter, 1939; Freeman, 1994). Therefore, we included firm size as a variable, measured by the natural logarithm of the total number of employees.

\section{Results}

\subsection{Descriptive statistics}

Table 2 provides an overview of the frequencies on structure variables for both the incremental and radical NPD processes. This frequency table clearly indicates that, for both the incremental and radical NPD processes, cross-functional structures are much more common than functional structures.

An overview of the descriptive statistics on the continuous variables can be found in Table 3. The means for the variables breakthrough innovation performance and incremental innovation performance are 3.07 and 3.39, respectively. Taking into account that this study uses logarithmic transformation for these variables, the implication is that, on average, the respondents attributed $25.91 \%$ of their turnover to breakthrough products and $31.69 \%$ to improved products. As we see in Table 3 , the control variables professionalization of NPD strategy and innovative climate significantly correlate with the dependent variables. We elaborate on these relationships below.

\subsection{The application of different structures for different NPD processes}

Table 4 shows which kinds of structures firms apply for their incremental and radical NPD processes. This table clearly 
Table 3

Descriptive statistics and correlations.

\begin{tabular}{|c|c|c|c|c|c|c|c|}
\hline Variable & Mean & $\begin{array}{l}\text { Standard } \\
\text { deviation }\end{array}$ & $\begin{array}{l}\text { Derivative } \\
\text { innovation } \\
\text { performance }\end{array}$ & $\begin{array}{l}\text { Breakthrough } \\
\text { innovation } \\
\text { performance }\end{array}$ & $\begin{array}{l}\text { Log } \\
\text { (Company } \\
\text { size) }\end{array}$ & $\begin{array}{l}\text { Professionali- } \\
\text { zation NPD } \\
\text { strategy }\end{array}$ & $\begin{array}{l}\text { Innovative } \\
\text { climate }\end{array}$ \\
\hline Incremental innovation performance & 3.3889 & .46088 & 1 & & & & \\
\hline Breakthrough innovation performance & 3.0660 & .87942 & $-.648^{* * *}$ & 1 & & & \\
\hline Log (Company size) & 5.2658 & 1.33460 & -.023 & -.001 & 1 & & \\
\hline Professionalization NPD strategy & 4.6710 & .98554 & $-.269^{* * *}$ & $.248^{* * *}$ & .079 & 1 & \\
\hline Innovative climate & 4.4860 & .86768 & $-.345^{* *}$ & $.224^{* * *}$ & .111 & $.435^{* *}$ & 1 \\
\hline
\end{tabular}

*Correlation is significant at the 0.05 level (two-tailed).

**Correlation is significant at the 0.01 level (two-tailed).

Table 4

Combinations of structures.

\begin{tabular}{lll}
\hline Incremental NPD process & Radical NPD process & \\
\cline { 2 - 3 } & $\begin{array}{l}\text { Functional } \\
\text { structure }\end{array}$ & $\begin{array}{l}\text { Cross-functional } \\
\text { structure }\end{array}$ \\
\hline $\begin{array}{l}\text { Functional structure } \\
\text { Cross-functional structure }\end{array}$ & $\begin{array}{r}9(5.8 \%) \\
11(20 \%)\end{array}$ & $104(67.1 \%)$ \\
\hline
\end{tabular}

illustrates that the majority of the responding firms apply a homogenous approach for structuring different kinds of NPD processes. In particular, $67.1 \%$ of the firms rely on cross-functional structures for both their incremental and radical NPD processes. At the same time, we observe that only $27.1 \%$ of the firms under study deploy a differentiated structure for their incremental and radical NPD processes. Hypothesis 1 is therefore not supported by our data.

\subsection{Impact of structure on derivative innovation performance}

As one dependent variable (breakthrough innovation performance) contained a substantial amount of left-censored values, we relied on Tobit regressions (McDonald and Moffitt, 1980) to analyze Hypotheses 2 and 3. Table 5 summarizes the findings of the Tobit analysis whereby derivative innovation performance acts as the dependent variable.

In line with Hypothesis 2, we find that organizations that rely on a cross-functional structure for their incremental NPD processes perform significantly lower on derivative innovation performance than organizations that apply a functional structure for their incremental NPD processes. It can also be observed that innovative climate has a significant negative impact on derivative innovation performance. Finally, we did not observe a significant relationship between professionalization of NPD strategy and derivative innovation performance nor did we observe significant industry or firm size effects for derivative innovation performance.

\subsection{Impact of process structure on breakthrough innovation performance}

Table 6 summarizes the findings of the Tobit analysis whereby breakthrough innovation performance acts as the dependent variable.

In line with Hypothesis 3, we observe that companies that rely on a cross-functional structure to organize their radical NPD processes outperform companies that do not apply a cross-functional approach for structuring radical NPD in terms of breakthrough innovation performance. We also observe a significant positive relationship between innovative climate and breakthrough innovation performance. We did not observe a significant relationship between professionalization of NPD strategy and breakthrough innovation performance, and no significant industry or firm size effects on breakthrough innovation performance were observed.

\section{Discussion and conclusion}

\subsection{Relevance of structural ambidexterity in NPD processes}

Relying on organizational learning theory (e.g., March, 1991; Levinthal and March, 1993), several scholars (e.g., Gibson and Birkenshaw, 2004; Raisch and Birkinshaw, 2008; O'Reilly and Tushman, 2004; Van Looy et al., 2005) have argued that, if a company wants to excel in both improving existing products (i.e., derivative innovation performance) and generating new products (i.e., breakthrough innovation performance), it should apply structural ambidexterity. Although the structural ambidexterity argument has become increasingly popular in the academic literature (Raisch et al., 2009), our data seem to suggest that the popularity of this strategy is rather low in the context of structuring NPD processes. Making an explicit distinction between the incremental and radical NPD processes in our survey, we were able to examine whether firms tend to apply a different structure for different kinds of NPD processes. However, our data show that the majority of respondent firms preferred a homogenous approach concerning their structure. In particular, $67.1 \%$ of the firms indicated that they used a cross-functional structure for both their incremental and radical NPD processes.

At the same time, though, our analyses of the impact of different structures (i.e., functional versus cross-functional) in different kinds of NPD processes (i.e., incremental versus radical) on different kinds of innovation performance (i.e., derivative versus breakthrough) indicate that organizations might indeed benefit from adopting structural ambidexterity. In line with previous research that focuses on the relationship between structures and performance on the project level (e.g., Olsen et al., 1995, 2001; Song and Xie, 2000), we found evidence that the effectiveness of cross-functional structures is different among different kinds of NPD processes. In particular, we observed that, while adopting a cross-functional structure-instead of a functional structure-in radical NPD processes has a significant positive impact on breakthrough innovation performance, the implementation of a cross-functional structure in incremental NPD processes has a significant negative impact on incremental innovation performance. 
Table 5

Results of Tobit analysis-dependent variable: derivative innovation performance $\left(N=155\right.$; pseudo- $\left.R^{2}=0.19\right)$.

\begin{tabular}{|c|c|c|c|c|}
\hline Variable & Estimate & Std. error & Chi-square & $\operatorname{Pr}>$ Chi-square \\
\hline Intercept & 4.7526 & 0.3026 & 246.73 & $<.0001$ \\
\hline \multicolumn{5}{|l|}{ Industry: (Reference category : Automotive) } \\
\hline Other & -0.1688 & 0.2243 & 0.57 & 0.4517 \\
\hline Chemical & -0.1546 & 0.1467 & 1.11 & 0.2921 \\
\hline Electronics & -0.2788 & 0.1813 & 2.36 & 0.1241 \\
\hline Instruments & -0.1690 & 0.1508 & 1.26 & 0.2623 \\
\hline Leather & -0.1374 & 0.1386 & 0.98 & 0.3215 \\
\hline Metal & -0.0472 & 0.1099 & 0.18 & 0.6674 \\
\hline Stone & -0.1445 & 0.1354 & 1.14 & 0.2860 \\
\hline Textile & -0.0242 & 0.1395 & 0.03 & 0.8623 \\
\hline Cross-functional structure for the incremental NPD process & -0.2670 & 0.1028 & 6.75 & 0.0094 \\
\hline Log (Company size) & 0.0088 & 0.0252 & 0.12 & 0.7262 \\
\hline Professionalization NPD strategy & -0.0530 & 0.0386 & 1.89 & 0.1696 \\
\hline Innovative climate & -0.1242 & 0.0324 & 14.69 & 0.0001 \\
\hline
\end{tabular}

Table 6

Results of Tobit analysis-dependent variable: breakthrough innovation performance $\left(N=155\right.$; pseudo- $\left.R^{2}=0.21\right)$

\begin{tabular}{|c|c|c|c|c|}
\hline Variable & Estimate & Std. error & Chi-square & $\operatorname{Pr}>$ Chi-square \\
\hline Intercept & 0.8645 & 0.5124 & 2.85 & 0.0916 \\
\hline \multicolumn{5}{|l|}{ Industry: (Reference category: Automotive) } \\
\hline Other & -0.7881 & 0.4478 & 3.10 & 0.0785 \\
\hline Chemical & 0.1858 & 0.2904 & 0.41 & 0.5223 \\
\hline Electronics & 0.3488 & 0.3599 & 0.94 & 0.3325 \\
\hline Instruments & 0.4149 & 0.2966 & 1.96 & 0.1619 \\
\hline Leather & 0.3430 & 0.2732 & 1.58 & 0.2094 \\
\hline Metal & 0.0141 & 0.2175 & 0.00 & 0.9484 \\
\hline Stone & 0.1659 & 0.2657 & 0.39 & 0.5323 \\
\hline Textile & -0.0139 & 0.2667 & 0.00 & 0.9583 \\
\hline Cross-functional structure for radical NPD process & 0.4629 & 0.1542 & 9.01 & 0.0027 \\
\hline Log (Company size) & -0.0174 & 0.0501 & 0.12 & 0.7281 \\
\hline Professionalization NPD strategy & 0.1042 & 0.0764 & 1.86 & 0.1727 \\
\hline Innovative climate & 0.1930 & 0.0650 & 8.81 & 0.0030 \\
\hline
\end{tabular}

\subsection{Impact of innovative climate on innovation performance}

Previously, scholars have argued that a strong organizational climate positively influences the innovation performance of firms (Ekvall, 1996; Prajogo and Sohal, 2001). Whereas these studies approached innovation performance in quite general terms, we have made an explicit distinction between derivative and breakthrough innovation performance and observed differentiated relationships.

We observed a positive impact of innovative climate on breakthrough innovation performance. The positive relationship between innovative climate and breakthrough performance can be explained by the complexity and uncertainty that characterize radical innovations. For breakthrough new products, where pioneering, risk taking, and developing entirely new competencies define the new product function, companies need an internal environment where managers support entrepreneurship and where creativeness and risk taking are rewarded so that they can explore and develop new creative concepts and technologies (De Brantani, 2000; Veryzer, 1998). At the same time, our data indicate a significant negative relationship between the strength of the organizational climate and derivative innovation performance. An explanation for this negative relationship might be that an organizational climate that heavily emphasizes entrepreneurship, risk taking, and freedom to experiment is less beneficial for conducting exploitative activities, which are necessary for derivative innovations (Li et al., 2008).

\subsection{Limitations and future research}

In this study we focused on one particular country (i.e., United States) whereas previous project-level research (e.g., Love and Roper, 2009; Song and Xie, 2000) has indicated that the relationship between structures, product innovativeness, and project performance is influenced by the national culture in which the firm is embedded. In a similar vein, it can be expected that national differences might influence the effect of structures on firm-level innovation performance. We therefore encourage researchers to conduct an international comparison of the impact of structures in different kinds of NPD processes on different kinds of innovation performance.

In this study, we made a distinction between functional and cross-functional structures. However, previous research on individual NPD projects (e.g., Olsen et al., 2001; Song et al., 1998; Souder, 1988) indicates that firms can implement different kinds of cross-functional structures. In particular, they have made a distinction between (1) cross-functional team structures in which R\&D, manufacturing, and marketing people are present and (2) cross-functional team structures in which only two departments are represented. As these studies provide indications that the particular composition of cross-functional teams might influence project performance, we suggest future firm-level research where more fine-grained measures for the applied structure are used.

It also needs to be pointed out that we focused on the difference between incremental and radical development process 
in terms of their structural antecedents. However, incremental and radical development processes can also be influenced by the presence (or absence) of critical roles such as idea generators, project champions, and gatekeepers (Roberts and Fusfeld, 1982). Investigating the effect of structural design choices combined with the presence of specific roles seems a logical next step to enrich our understanding of antecedents of different kinds of innovation outcomes.

In this study we found evidence that the effectiveness of functional and cross-functional structures is different among different kinds of NPD processes. A logical next question then becomes whether firms adopting structural ambidexterity for their activities indeed outperform their counterparts in terms of overall innovative performance. Unfortunately our research design did not allow for this question to be addressed properly ${ }^{7}$; following our findings, future research should address this important suggestion.

Although we were able to examine which kind of structure firms applied for their incremental and radical NPD processes, we do not know why firms chose a particular structure. This latter question seems to be very relevant as we observed that firms tend to prefer a homogeneous approach (i.e., cross-functional structure for both incremental and radical NPD processes) despite the fact that we found clear indications of the benefits of adopting a more diversified approach (i.e., functional structure for the incremental NPD processes and cross-functional structure for the radical NPD processes).

A potential explanation for the firms' preference for a homogeneous approach might be that adopting a more differentiated approach triggers additional coordination and integration costs across different NPD processes. We therefore emphasize the need for future research that provides fine-grained insights into why companies make particular structural choices for their NPD activities and how these choices influence the financial costs and benefits of the firm. Such research requires a design in which data on innovation activities and innovation performance are linked to financial firm data (see Uotila et al., 2009, for a recent example of such a design).

\subsection{Conclusion}

This article has provided a firm-level perspective on the management of NPD processes, acknowledging the relevance of adopting different structures in different NPD processes. We hope that NPD managers will consider our practical suggestions and that our results may motivate researchers to continue exploring the NPD process in a wide variety of organizational settings.

\section{References}

Allen, T.J., 2001. Organizing for product development. MIT Sloan Working Paper 422901.

\footnotetext{
${ }^{7}$ Recent ambidexterity research (e.g., He and Wong, 2004; Jansen et al., 2009) has measured overall performance by developing an aggregate construct, representing the sum of different kinds of innovation performance. The reasoning behind this measurement is that the higher the score on this aggregate construct, the higher the ability of the firm to combine different kinds of innovation activities. However, as we work with proportional measures of derivative and breakthrough innovation performance, we could not construct such an aggregate measure.
}

Balbontin, A., Yazdani, B., Cooper, R., Souder, W.E., 1999. New product development success factors in American and British firms. International Journal of Technology Management 17, 259-279.

Barczak, G., Griffin, A., Kahn, K.B., 2009. Perspective: trends and drivers of success in NPD practices: results of the 2003 PDMA best practices study. Journal of Product Innovation Management 26, 3-23.

Baumol, W.J., 2002. In: The Free-Market Innovation Machine. Princeton University Press, Princeton.

Benner, M.J., Tushman, M.L., 2003. Exploitation, exploration, and process management: the productivity dilemma revisited. Academy of Management Journal 28 (2), 238-256.

Booz, Allen, Hamilton, 1982. In: New Products Management for the 1980s. Booz Allen and Hamilton, New York.

Brown, S.L., Eisenhardt, K.M., 1995. Product development: past research, present findings, and future directions. Academy of Management Review 20, 343-378.

Canez, L., Puig, L., Quintero, R., Garfias, M., 2007. Linking technology acquisition to a gated NPD process. Research Technology Management 50 (4), 49-55.

Cooper, R.G., Kleinschmidt, E.J., 1995. Benchmarking the firm's critical success factors in new product development. Journal of Product Innovation Management 12 (5), 374-391.

Cooper, R.G., 1996. New products: what separates the winners from the Losers. In: Rosenau Jr., M.D. (Ed.), PDMA Handbook for New Product Development. John Wiley, New York.

Cooper, R.G., 1999. The invisible success factors in product innovation. Journal of Product Innovation Management 16, 115-133.

Cooper, R.G., 2001. In: Winning at New Products: Accelerating the Process from Idea to Launch third ed. Perseus Books, Reading.

Cooper, R.G., 2003. Overcoming the crunch in resources for new product development. Research Technology Management 46 (3), 48.

Cooper, R.G., Edgett, S., Kleinschmidt, E.J., 2004. Benchmarking Best NPD Practices-II. Research Technology Management 4 (3), 50-59.

Cooper, R.G., Edgett., S.J., 2008. Maximizing productivity in product innovation. Research Technology Management 51 (2), 47-58.

Cormican, K., O'Sullivan, D., 2004. Auditing best practice for effective product innovation management. Technovation 24, 819-829.

Damanpour, F. 1991. Organizational innovation: a meta-analysis of the effects of determinant and moderators. Academy of Management Journal 34, 555-590.

De Brantani, U., 2000. Innovative versus incremental new business services: different keys for achieving success. Journal of Product Innovation Management $18,169-187$.

Dewar, R.D., Dutton, J.E., 1986. The adoption of radical and incremental innovations: an empirical analysis. Management Science 32, 1422-1433.

Dillman, D.A., 1978. In: Mail and Telephone Surveys: The Total Design Method. Wiley-Interscience, New York.

Eisenhardt, K.M., Tabrizi, B.N., 1995. Accelerating adaptive processes: product innovation in the global computer industry. Administrative Science Quarterly 40, 84-110.

Ekvall, G., 1996. Organizational climate for creativity and innovation. European Journal of Work and Organizational Psychology 5 (1), 105-123.

Ernst, H., 2002. Success factors of new product development: a review of the empirical literature. International Journal of Management Reviews 4 (1), 1-40.

Faems, D., Van Looy, B., Debackere, K., 2005. Interorganizational collaboration and innovation: toward a portfolio approach. Journal of Product Innovation Management 22 (3), 238-250.

Freeman, C., 1994. The economics of technical change. Cambridge Journal of Economics 18 (5), 463-514.

Garcia, N., Sanzo, M.J., Trespalacios, J.A., 2008. New product internal performance and market performance: evidence from Spanish firms regarding the role of trust, interfunctional integration, and innovation type. Technovation 28, 713-725.

Gibson, C.B., Birkinshaw, J., 2004. The antecedents, consequences, and mediating role of organizational ambidexterity. Academy of Management Journal 47, 209-226.

Griffin, A., 1997. PDMA research on new product development practices: updating trends and benchmarking best practices. Journal of Product Innovation Management 14, 429-458.

Griffin, A., Hauser, J., 1992. Patterns of communication among marketing, engineering and manufacturing - a comparison between two new product teams. Management Science 38, 360-373.

Griffin, A., Page, A.L., 1996. PDMA success measurement project: recommended measures for product development success and failure. Journal of Product Innovation Management 13, 478-496.

Gupta, A., Raj, S.P., Wilemon, D.A., 1986. A model for studying R\&D-marketing interface in the product innovation process. Journal of Marketing 13, 191-215.

Gupta, A.K., Smith, K.G., Shalley, C.E., 2006. The interplay between exploration and exploitation. Academy of Management Journal 49 (4), 693-706.

Hargadon, A., 2003. In: How Breakthroughs Happen: The Surprising Truth about how Companies Innovate. Harvard Business School Press, Boston, MA.

He, Z.L., Wong, P.K., 2004. Exploration vs. exploitation: an empirical test of the ambidexterity hypothesis. Organization Science 15, 481-494.

Jansen, J.J.P., Tempelaar, M.P., Van den Bosch, F.A.J., Volberda, H.W., 2009. Structural differentiation and ambidexterity: the mediating role of integration mechanisms. Organization Science 20 (4), 797-811.

Jansen, J.J.P., Van den Bosch, F.A.J., Volberda, H.W., 2006. Exploratory innovation, exploitative innovation, and performance: effects of organizational antecedents and environmental moderators. Management Science 52, 1661-1674. 
Lee, C., Chen, W.-J., 2007. Cross-functionality and charged behavior of the new product development teams in Taiwan's information technology industries. Technovation 27, 605-615.

Levinthal, D.A., March, J.G., 1993. The myopia of learning. Strategic Management Journal 14, 95-112.

Li, Y., Vanhaverbeke, W., Schoenmakers, W., 2008. Exploration and exploitation in innovation: reframing the interpretation. Journal of Creativity and Innovation Management 17 (2), 107-126.

Love, J.H., Roper, S., 2009. Organizing innovation: complementarities between cross-functional teams. Technovation 29, 192-203.

March, J.G., 1991. Exploration and exploitation in organizational learning. Organization Science 2, 71-88.

McDonald, J.F., Moffitt, R.A., 1980. The uses of Tobit analysis. Review of Economics and Statistics 62 (2), 318-321.

Moenaert, R.K., DeMeyer, A., Souder, W.E., Deschoolmeester, D., 1995. R\&D/ marketing communication during the fuzzy front-end. IEEE Transactions on Engineering Management 42, 243-258.

Olsen, E.M., Walker, O.C., Ruekert, R.W., 1995. Organizing for effective new product development: the moderating role of product innovativeness. Journal of Marketing 59 (1), 48-62.

Olsen, E.M., Walker, O.C., Ruekert, R.W., Bonner, J.M., 2001. Patterns of cooperation during new product development among marketing, operations and R\&D: implications for project performance. Journal of Product Innovation Management 18, 258-271.

O'Reilly, C.A., Tushman, M.L., 2004. The ambidextrous organization. Harvard Business Review 82 (4), 74-82.

Parry, M.E., Song, X.M., De Weerd-Nederhof, P.C., Visscher, K., 2009. The impact of NPD strategy, product strategy, and NPD processes on perceived cycle time. Journal of Product Innovation Management 26, 627-639.

Pelz, D.C., Andrews, F.M., 1966. In: Scientists in Organizations. John Wiley, New York

Pinto, M.B., Pinto, J.K., 1990. Project team communication and cross-functional cooperation in new program development. Journal of Product Innovation Management 7, 200-212.

Prajogo, D.I., Sohal, A.S., 2001. TQM and innovation: a literature review and research framework. Technovation 21, 539-558.

Raisch, S., Birkinshaw, J., 2008. Organizational ambidexterity: antecedents, outcomes, and moderators. Journal of Management 34 (3), 375-409.

Raisch, S., Birkinshaw, J., Probst, G., Tushman, M.L., 2009. Organizational ambidexterity: balancing exploitation and exploration for sustained performance. Organization Science 20, 685-695.

Roberts, E.B., Fusfeld, A.R., 1982. Critical functions: needs and roles in the innovation process. In: Katz, R. (Ed.), Career Issues in Human Resource Management. Prentice-Hall, Englewood Cliffs, NJ, pp. 182-207.

Rothaermel, F.T., Deeds, D.L., 2004. Exploration and exploitation alliances in bitechnology: a system of new product development. Strategic Management Journal 25, 201-221.

Ruekert, R.W., Walker, O., 1987. Marketing's interaction with other functional units: a conceptual framework and empirical evidence. Journal of Marketing 51,1-19.

Sánchez, A.M., Pérez, M.P., 2003. Flexibility in new product development: a survey of practices and its relationship with the product's technological complexity. Technovation 23, 139-145.

Schmidt, J.B., Sarangee, K., Montoya, M.M., 2009. Exploring new product development project review practices. Journal of Product Innovation Management 26 (5), 520-535.

Schön, D., 1963. In: Invention and the evolution of ideas-the displacement of concepts. Travistock Publications.

Schumpeter, J.A., 1939. In: Business Cycles: A Theoretical, Historical, and Statistical Analysis of the Capitalist Process. McGraw-Hill, New York

Song, X.M., Montoya-Weiss, M.M., Schmidt, J.B., 1997. Antecedents and consequences of cross-functional cooperation: a comparison of R\&D, manufacturing and marketing perspectives. Journal of Product Innovation Management 14, 35-47.

Song, X.M., Thieme, R.J., Xie, J., 1998. The impact of cross-functional joint involvement across product development stages: an exploratory study. Journal of Product Innovation Management 15, 289-303.

Song, X.M., Xie, J., 2000. Does innovativeness moderate the relationship between cross-functional integration and product performance?. Journal of international marketing 8 (4), 61-89.

Souder, W.E., 1988. Managing relations between R\&D and marketing in new product development projects. Journal of Product Innovation Management 5, 6-19.

Tushman, M.L., Anderson, P., 1986. Technological discontinuities and organizational environments. Administrative Science Quarterly 31, 439-465.

Tushman, M.L., O'Reilly, C.A., 1996. Ambidextrous organizations: managing evolutionary and revolutionary change. California Management Review 38, 8-30.

Tushman, M.L., Smith, W.K., 2002. Organizational technology. In: Baum, J. (Ed.), Companion to Organization. Blackwell, Malden MA, pp. 386-414

Uotila, J., Maula, M., Keil, T., Zahra, S., 2009. Exploration, exploitation, and financial performance: analysis of S\&P 500 corporations. Strategic Management Journal 30, 221-231.

Veryzer, R.W., 1998. Key factors affecting customer evaluation of discontinuous new products. Journal of Product Innovation Management 15 (4), 136-150.

Van Der Vegt, G.S., Van De Vliert, E., Huang, X., 2005. Location-level links between diversity and innovative climate depend on national power distance. Academy of Management Journal 48 (6), 1171-1182.

Van Looy, B., Martens, T., Debackere, K., 2005. Organizing for continuous innovation: on the sustainability of ambidextrous organizations. Creativity and Innovation Management 14 (3), 208-221.
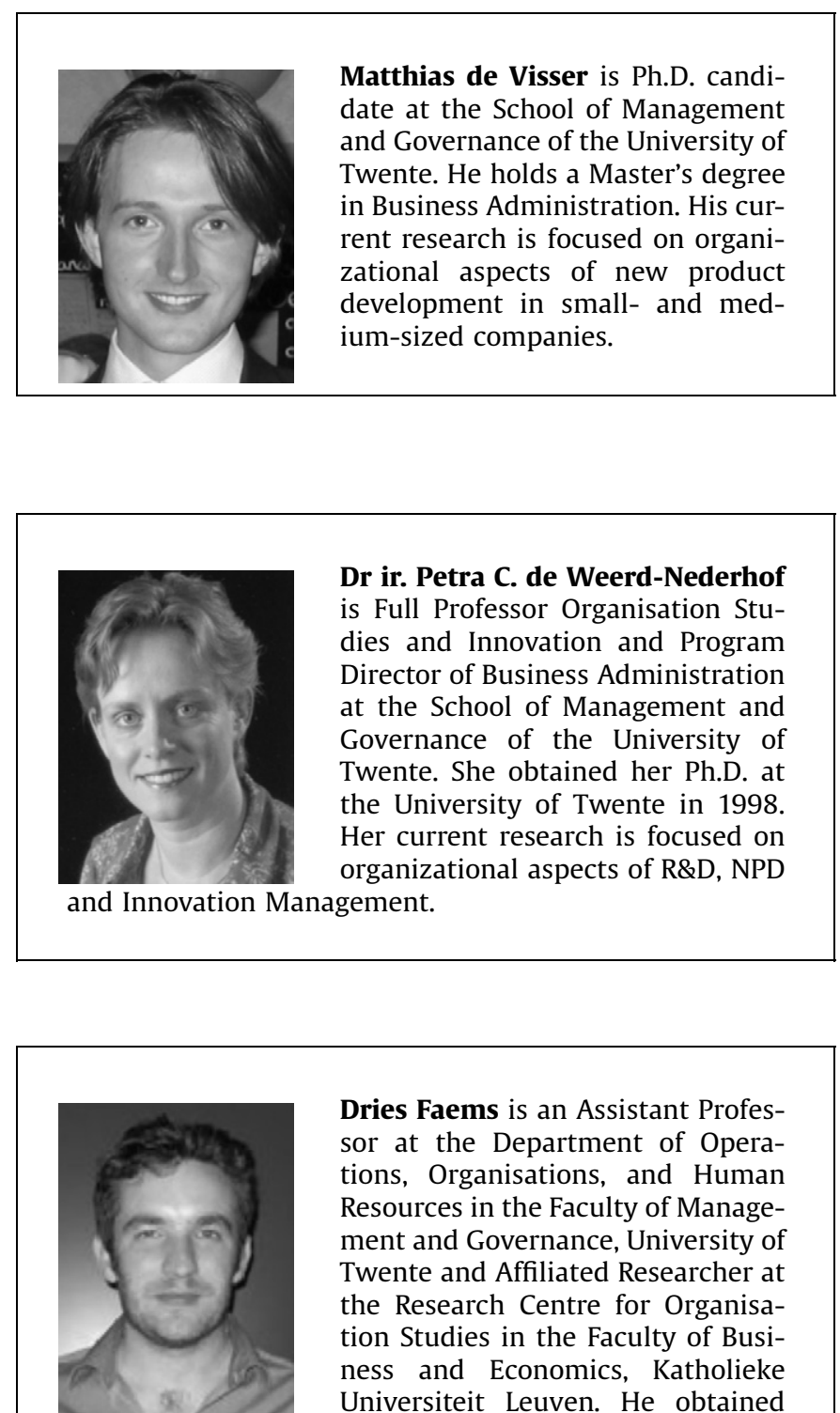

Dries Faems is an Assistant Professor at the Department of Operations, Organisations, and Human Resources in the Faculty of Management and Governance, University of Twente and Affiliated Researcher at the Research Centre for Organisation Studies in the Faculty of Business and Economics, Katholieke Universiteit Leuven. He obtained his Ph.D. in Applied Economics from Katholieke Universiteit Leuven. His current research focuses on governance processes in R\&D alliances and performance implications of alliance portfolios.

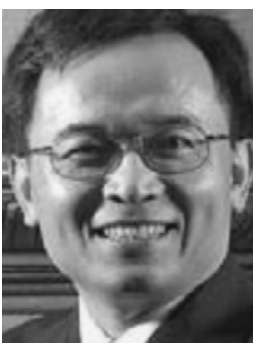

Michael Song holds the Charles N. Kimball, MRI/Missouri Endowed Chair in Management of Technology and Innovation and is professor of Marketing at the Bloch School of Business and Public Administration, University of Missouri-Kansas City. He is Director of the Institute for Entrepreneurship and Innovation at the Bloch School. Song's current research interests include technology entrepreneurship, valuation of new ventures and emerging technologies, risk assessment, methods for measuring values of technology and R\&D projects, and technology portfolio management. 

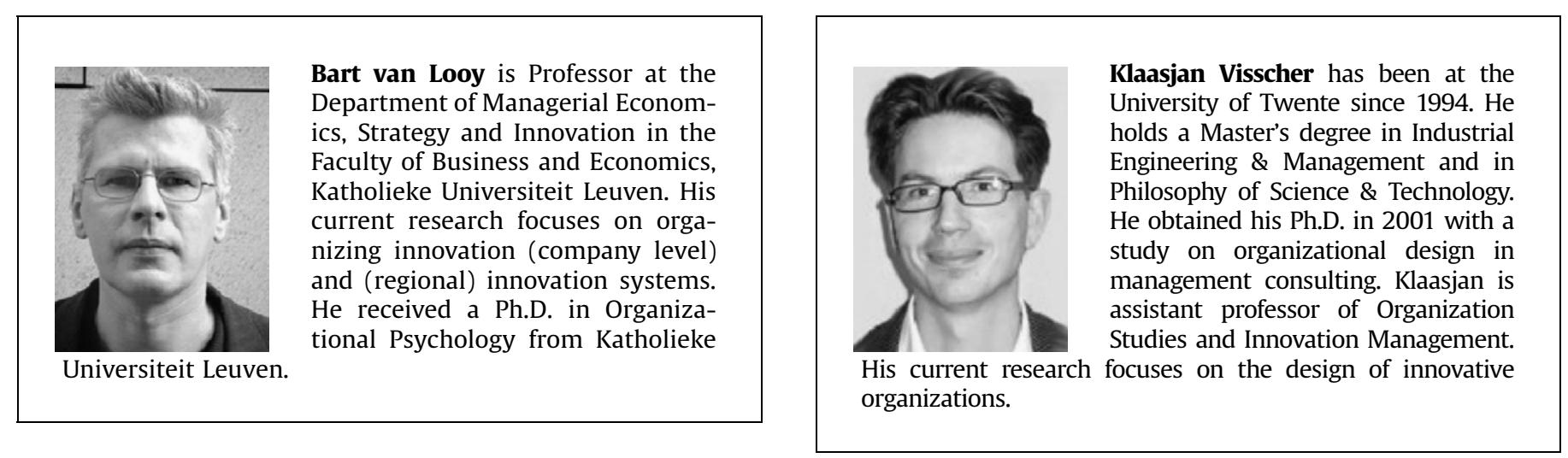